\title{
The validity of infrared coagulator, and BioGlue with antibiotics to assist surgical treatment of infective endocarditis?
}

\author{
Gosta Pettersson $^{1}$, Shinya Unai ${ }^{1}$, Steven Gordon ${ }^{2}$, Syed T. Hussain ${ }^{3}$, Elof Eriksson ${ }^{4,5}$ \\ ${ }^{1}$ Heart and Vascular Institute, Department of Thoracic and Cardiovascular Surgery, ${ }^{2}$ Medicine Institute, Department of Infectious Disease, \\ Department of Cardiovascular Medicine, Cleveland Clinic, Cleveland, OH, USA; ${ }^{3}$ Department of Cardiovascular \& Thoracic Surgery, Donald and \\ Barbara Zucker School of Medicine at Hofstra/Northwell, Northwell, Health/Southside Hospital, Bay Shore, NY, USA; ${ }^{4}$ Professor Emeritus at \\ Harvard Medical School, Boston, MA, USA; ${ }^{5}$ Chief Medical Officer at Applied Tissue Technologies, Hingham, MA, USA \\ Correspondence to: Gosta Pettersson. Heart and Vascular Institute, Department of Thoracic and Cardiovascular Surgery, Cleveland Clinic, 9500 Euclid \\ Avenue/J4, Cleveland, OH 44195, USA. Email: PETTERG@ccf.org. \\ Provenance and Peer Review: This article was commissioned by the editorial office, Fournal of Thoracic Disease. The article did not undergo external peer review. \\ Comment on: Kubota H, Endo H, Ishii H, et al. An infrared coagulator to assist surgical treatment of infective endocarditis. J Thorac Dis \\ 2019;11:4364-70.
}

Submitted Feb 01, 2020. Accepted for publication Mar 09, 2020.

doi: $10.21037 /$ jtd.2020.03.95

View this article at: http://dx.doi.org/10.21037/jtd.2020.03.95

Dr. Kubota and colleagues (1) have applied a new infrared coagulator to assist surgical treatment of infective endocarditis (IE). The thermal effect was applied as a means of achieving a bactericidal effect in the treatment of IE. Temperatures between 72 and $75^{\circ} \mathrm{C}$ destroy pathogenic organisms including bacteria and viruses. This is a new principle for achieving a "sterile" surface of infected areas. This technique and principle have been successfully used in 15 cases. The overall follow up of the authors' series is limited, and extent of invasive disease beyond the valve leaflet not described (2). The results are impressive if they hold up over time.

However, the report includes a detailed description of one case of invasive aortic valve endocarditis, the management raises several questions: "Two large annular abscess orifices were identified, one beneath the left coronary artery orifice and the other beneath the right coronary artery orifice. Curettage was performed on the margin the abscess orifices, but in order to prevent coronary artery injury and prevent complete aorto- left ventricular dehiscence we were careful not to perform excessive debridement, and thus, fragile inflammatory tissue around the orifices remained. Infrared ablation was applied until the fragile tissue became dry and discolored. After ablating the entire margins of the orifices, both abscess cavities were filled with biological glue containing the antibiotic Amikacin, and the orifices patched with xenopericardium."

This case description violates basic principles described in the recent AATS guidelines of surgical treatment of endocarditis (3): it is a fundamental surgical principle to remove infected material, foreign bodies, and necrotic tissue to minimize the residual infectious burden and provide optimal access for hostdefense and antimicrobial therapy by surrounding the area with bealthy well-vascularized tissue. Infected areas must be opened and unroofed and all infected pockets cleaned out. Instead the authors cauterize the surface of the infected areas with the infrared coagulator and fill the abscess cavities with a fibrinogen/ factor XIII sealant including an antibiotic. The AATS guidelines say: "Debridement is followed by generous irrigation. Many surgeons use local antiseptics and antimicrobials, but no studies specific to IE support the value of this practice." Many surgeons still use local antibiotics to reduce the number of live residual bacterial but coagulation of the surface tissue is new. The authors also claim that the coagulation results in firmer tissue to sew to. We are skeptical but not completely dismissive of the principles introduced by the authors but the report raises many questions which require translational 
research related to the validity of these principles:

Is it better to coagulate than to remove all infected and necrotic tissue? - we are not convinced! If the coagulated tissue is dead, it would become a substrate for any residual bacteria. In burn injuries to skin and superficial muscle there is often an abscess layered between dead and live tissues. This is likely to happen also in the heart.

Is it true that coagulation improves quality of edematous fragile tissue and allows such tissue to hold sutures better? - over time the necrotic tissue will disintegrate. We have demonstrated excellent results in patients who have prosthetic valve endocarditis with thorough debridement of all infected foreign material and necrotic tissue and replacement of the aortic root with an allograft (4) and many others have demonstrated similar results with other conduits. Using allograft to reconstruct the root, additional materials are almost never required, and if needed autologous pericardium is our preference.

Sterilizing infected cavities, which cannot be left open and communicating with the blood stream or the pericardium remains an interesting principle and more so for patients with invasive mitral valve and invasion to the atrioventricular grove, than for patients with aortic valve endocarditis.

The authors also need to specify the amount and concentration of amikacin that they use and what the release characteristics are.

\section{Acknowledgments}

Funding: None.

\section{Footnote}

Conflicts of Interest: All authors have completed the ICMJE uniform disclosure form (available at http://dx.doi. org/10.21037/jtd.2020.03.95). The authors have no conflicts of interest to declare.

Ethical Statement: The authors are accountable for all aspects of the work in ensuring that questions related to the accuracy or integrity of any part of the work are appropriately investigated and resolved.

Open Access Statement: This is an Open Access article distributed in accordance with the Creative Commons Attribution-NonCommercial-NoDerivs 4.0 International License (CC BY-NC-ND 4.0), which permits the noncommercial replication and distribution of the article with the strict proviso that no changes or edits are made and the original work is properly cited (including links to both the formal publication through the relevant DOI and the license). See: https://creativecommons.org/licenses/by-nc-nd/4.0/.

\section{References}

1. Kubota H, Endo H, Ishii H, et al. An infrared coagulator to assist surgical treatment of infective endocarditis. J Thorac Dis 2019;11:4364-70.

2. Pettersson GB, Hussain ST, Shrestha NK, et al. Infective endocarditis: an atlas of disease progression for describing, staging, coding, and understanding the pathology. J Thorac Cardiovasc Surg 2014;147:1142-1149.e2 .

3. AATS Surgical Treatment of Infective Endocarditis Consensus Guidelines Writing Committee Chairs, Pettersson GB, Coselli JS, et al. 2016 The American Association for Thoracic Surgery (AATS) consensus guidelines: Surgical treatment of infective endocarditis: Executive summary. J Thorac Cardiovasc Surg 2017;153:1241-1258.e29.

4. Sabik JF, Lytle BW, Blackstone EH, et al. Aortic root replacement with cryopreserved allograft for prosthetic valve endocarditis. Ann Thorac Surg 2002;74:650-9; discussion 659
Cite this article as: Pettersson G, Unai S, Gordon S, Hussain ST, Eriksson E. The validity of infrared coagulator, and BioGlue with antibiotics to assist surgical treatment of infective endocarditis? J Thorac Dis 2020;12(7):3473-3474. doi: 10.21037/ jtd.2020.03.95 